CLINICAL STUDY

\title{
A case of primary aldosteronism in pregnancy: do LH and GNRH receptors have a potential role in regulating aldosterone secretion?
}

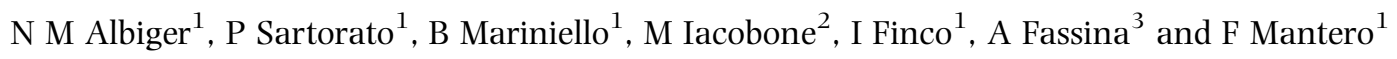 \\ ${ }^{1}$ Division of Endocrinology, Department of Medical and Surgical Sciences, ${ }^{2}$ Endocrine Surgery Unit, Department of Surgical and Gastroenterological \\ Sciences and ${ }^{3}$ Section of Pathology and Cytopathology, Department of Diagnostic Medical Sciences and Special Therapies, University of Padua, Via Ospedale \\ 105, 35128 Padua, Italy \\ (Correspondence should be addressed to N M Albiger; Email: nora.albiger@unipd.it)
}

\begin{abstract}
Objective: The mechanisms inducing steroidogenesis in primary aldosteronism (PA) remain poorly defined. It was recently demonstrated that some G-protein-coupled receptors are abnormally expressed in aldosterone-producing adenomas (APA). We evaluated the potential role of LH and GNRH receptors (LHR (or LHCGR) and GNRHR) in regulating aldosterone secretion in a patient with APA arising during pregnancy (index case) and in a subset of other patients with PA.

Patients and methods: GNRH test was performed in the index case, 11 other PA, and 5 controls. GNRHR and LHR expressions were examined in 23 APA and 6 normal tissues.

Results: Aldosterone response increased significantly (114\%) in the index case after GNRH test was performed preoperatively, while it was blunted after adrenalectomy. Aldosterone also increased after human chorionic gonadotropin and triptorelin stimulation. A partial aldosterone response to GNRH was observed in other 7/11 PA, while a significant response was observed in two patients. Controls did not respond to GNRH test.

GNRHR was overexpressed and LHR expression was moderate in the APA tissue from the index case. Moreover, LHR was found in normal adrenals and overexpressed in 6/22 APA. GNRHR was overexpressed in 6/22 APA, 2 of them with a 95- and 109-fold higher expression than normal. A correlation between the clinical and molecular findings was observed in five out of seven patients. Conclusion: We describe a case of PA diagnosed during pregnancy, which appeared to correlate with aberrant LHR and GNRHR expression. Our findings suggest that a subset of patients with PA has aberrant LHR and GNRHR expression, which could modulate aldosterone secretion.
\end{abstract}

European Journal of Endocrinology 164 405-412

\section{Introduction}

The mechanisms involved in the synthesis of steroids by adrenal adenoma or hyperplasia remain to be clarified. It has clearly been demonstrated that, in some cases of Cushing's syndrome from adrenal adenoma or bilateral adrenal hyperplasia, cortisol secretion may be regulated by the presence of hormone receptors aberrantly expressed in the adrenal tissue (1). Such evidence can help to explain the mechanisms regulating steroid secretion, as well as offering an opportunity to identify new therapeutic strategies to suppress the endogenous ligands or block the receptor with specific antagonists (2).

Only a few studies have examined the possible role of the aberrant expression of G-protein-coupled receptors (GPCRs) in the adrenocortical tissue of patients with aldosterone-producing adenomas (APA) (3-5). Although an overexpression of LH and/or GNRH receptors (LHR and GNRHR) has been demonstrated in some APA $(6,7)$, less is known about the aldosterone response to in vivo GNRH or LH in these patients (8).

In this study, we describe the aldosterone response to GNRH in a patient with primary aldosteronism (PA), first diagnosed during pregnancy, and in a group of patients with PA, for whom we examined the GNRHR and LHR expressions in adrenal tissues to evaluate their role as potential regulators of aldosterone secretion.

\section{Subjects and methods}

\section{Clinical case}

A 32-year-old female patient came to our center to be assessed for arterial hypertension (blood pressure levels of $155 / 95 \mathrm{mmHg}$ ), first diagnosed at 28 weeks of 
pregnancy. Biochemical analysis showed hypokalemia (3.0 $\mathrm{mmol} / \mathrm{l})$, and upright aldosterone and plasma renin activity (PRA) were analyzed $(59.0 \mathrm{ng} / \mathrm{dl}$ and $0.3 \mathrm{ng} / \mathrm{ml}$ per hour respectively; aldosterone/PRA ratio: 196). She was treated with calcium blockers and potassium, and a Cesarean section was performed at 36 weeks of gestation. The patient gave birth to a healthy baby. Blood pressure immediately after delivery was $180 / 120 \mathrm{mmHg}$ and subsequently hyperaldosteronism was confirmed: upright aldosterone, $61.6 \mathrm{ng} / \mathrm{dl}$; upright plasma PRA, $0.2 \mathrm{ng} / \mathrm{ml}$ per hour; aldosterone/ PRA ratio, 306; $\mathrm{K}, 2.2 \mathrm{mmol} / \mathrm{l}$; aldosterone and PRA after oral captopril $50 \mathrm{mg}, 125.8 \mathrm{ng} / \mathrm{dl}$ and $0.1 \mathrm{ng} / \mathrm{ml}$ per hour respectively; aldosterone and PRA after $4 \mathrm{~h}$ i.v. saline loading, $63 \mathrm{ng} / \mathrm{dl}$ and $0.2 \mathrm{ng} / \mathrm{ml}$ per hour respectively.

Abdominal magnetic resonance imaging (MRI) showed a solid adrenal mass of $2 \times 1 \times 1 \mathrm{~cm}$ on the left side. Adrenal venous sampling resulted in aldosterone hypersecretion on the left side. A left laparoscopic adrenalectomy was performed. Histology of the excised adrenal gland revealed a cortical adenoma composed of zona glomerulosa-like cells.

One month after the surgery, blood pressure and serum potassium had returned to normal $(120 / 70 \mathrm{mmHg}$ and $3.8 \mathrm{mmol} / \mathrm{l}$ respectively) without medication and remained so throughout the follow-up.

\section{In vivo studies}

We studied 12 patients (including the index case) with a diagnosis of PA ( 6 women and 6 men; mean age at diagnosis $49 \pm 14$ years; 9 with APA and 3 with adrenal hyperplasia, AH) seen between 2004 and 2008 at the Endocrine Unit of Padua University Hospital. Another five healthy subjects were considered as a control group.

The diagnosis of PA was suspected on the basis of high upright plasma aldosterone, low PRA levels, and an increased aldosterone/PRA ratio $(>40)$. The diagnosis was confirmed when the aldosterone/PRA ratio was $>30$ and aldosterone levels were $\geq 7 \mathrm{ng} / \mathrm{dl}$ after captopril and saline infusion challenges respectively (9). Computed tomography or MRI was used in all patients to assess adrenal morphology. Adrenal venous sampling was also performed in 11/12 patients.

Aldosterone response to GNRH stimulation was assessed in the 12 patients with PA and the 5 controls. GNRH, $100 \mu \mathrm{g}$ i.v. (Relefact, Gonadorelin, Aventis, Frankfurt, Germany) was infused while the patient lay supine for at least $1 \mathrm{~h}$ after an overnight fast. Patients were considered for evaluation after at least a 20-day washout of any therapy for hypertension (in cases of severe hypertension, a calcium channel blocker was administered). Hypokalemia was corrected before performing the tests. An i.v. catheter was inserted and kept pervious with a slow flow of glucose solution throughout the test. Serial measurements of LH, PRA, aldosterone, and cortisol were obtained at $30 \mathrm{~min}$ intervals for $3 \mathrm{~h}$ during the course of the test.

Aldosterone response to GNRH stimulation test was expressed as the percentage of maximum aldosterone increase over the baseline (considered as 100\%). A positive response was defined as a more than 50\% increase in aldosterone following stimulation. A partial response was recorded if the aldosterone response was between 25 and $50 \%$.

The index case was also assessed after administering chorionic gonadotropin (hCG) 5000 IU i.m. (Profasi, Serono, Italy). Aldosterone, PRA, and cortisol were measured at $30 \mathrm{~min}$ intervals for $4 \mathrm{~h}$ and then again after $24 \mathrm{~h}$. Serial measurements of aldosterone, PRA, cortisol, LH, and potassium were also obtained every 2-4 days for 30 days after administering the i.m. GNRH analog (Triptorelin $3.75 \mathrm{mg}$ ). The acute GNRH stimulation test was repeated in the patient a month after the adrenal surgery.

The study was performed in accordance with the Helsinki II Declaration and approved by the local ethical committee at the University of Padua. Informed consent was obtained from all patients and controls.

\section{Hormone assays}

Plasma aldosterone was assayed using a commercial kit (Aldosterone Mirya, Technogenetics, Cassina de Pecchi, Italy); the intra- and inter-assay coefficients of variation $(\mathrm{CV})$ for this test were both $<5.6 \%$. PRA was measured by RIA with a commercial kit (Ren CTK, DiaSorin Biomedica, Saluggia, Italy), and the intra- and inter-assay $\mathrm{CV}$ values were within 8 and $10 \%$ respectively. Cortisol was measured by RIA (DiaSorin Diagnostics, Saluggia, Italy) with intra- and inter-assay $\mathrm{CV}$ values of 5.4 and $9.6 \%$ respectively. $\mathrm{LH}$ was measured by IRMA using a commercial kit (Adaltis Italia, Bologna, Italy) with a detection limit of $0.1 \mathrm{IU} / \mathrm{l}$; the inter- and intra-assay $\mathrm{CV}$ values were $<10$ and $5 \%$ respectively.

\section{Real-time RT-PCR quantification}

LHR and GNRHR expressions were assessed in 23 adrenal tissues obtained from patients with PA (21 APA and 2 macronodular hyperplasia) and 6 normal adrenal glands obtained after the surgery for renal transplantation.

The adrenocortical tissues were stored in RNAlater (Ambion, Foster City, CA, USA) and mRNA was isolated using the TriZol reagent (Invitrogen) according to the manufacturer's protocol.

Real-time PCR was performed in a total volume of $30 \mu \mathrm{l}$ per reaction adopting the reaction parameters recommended by the manufacturer, using a power SYBR Green PCR Master Mix (Applied Biosystems, Monza, Italy), and $50 \mathrm{nM}$ of each primer - except for $\beta$-actin, which was used at $30 \mathrm{nM}$ and $20 \mathrm{ng}$ cDNA. 
All reactions were performed for LHR and the housekeeping gene $\left(\beta\right.$-actin) at the same time. Data were obtained as $C_{t}$ values according to the guidelines (the cycle number at which logarithmic PCR plots cross a calculated threshold) and were used to determine $\Delta C_{\mathrm{t}}$ values $\left(\Delta C_{\mathrm{t}}=C_{\mathrm{t}}\right.$ of the target gene $-C_{\mathrm{t}}$ of the housekeeping gene). The equation $2^{-\Delta \Delta C_{\mathrm{t}}}$ was used to calculate the fold changes in gene expression between the patient and controls. Measurements were taken at least three times for each sample. We used $C_{t}=39$ as the cutoff for considering the real-time results as positive. Standard curves with increasing concentrations of $\operatorname{cDNA}(5,10$, 20,40 , and $80 \mathrm{ng}$ ) obtained from a pool of normal adrenals were obtained for all genes to verify the reaction efficiency: this was judged to be good when the slope came between 3.2 and 3.6. Water was used as a nontemplate control, while nonreverse-transcribed samples were run in parallel with the reverse-transcribed samples to rule out false-positive reactions.

The primers for amplification of the target sequences were based on published sequences for human $L H R, \mathrm{~F}$ 5'-TCTGGAGAAGATGCACAATGGA-3' and R 5'-GCCTGCAATTTGGTGGAAGA-3'; for GNRHR, F 5'-GGACCGCTCCCTGGCTAT- ${ }^{\prime} \mathrm{e}$ and $\mathrm{R} 5^{\prime}$-ACTGTCCGACTTTGCTGTTGCT-3'; and for $\beta$-actin, F $5^{\prime}$-CCTGGCACCCAGCACAAT-3' and R 5'-GCCGATCCACACGGAGTACT-3'.

\section{Immunohistochemistry}

For LHR, the immunohistochemical evaluation was performed on 14 pathological tissues from patients with PA, including the clinical case, and for GNRHR it was performed on 7 pathological tissues.

Immunohistochemistry (IHC) was performed using an automatic immunostaining device (Vision BioSystems 'Define' Polymer Detection System, Vision BioSystems, Newcastle, UK), with a Bond-maX immunostainer (Vision BioSystems), on sections $5 \mathrm{~mm}$ thick obtained from formalin-fixed, paraffin-embedded tissues. Sections were transferred to adhesive slides and dried at $62{ }^{\circ} \mathrm{C}$ for $30 \mathrm{~min}$. The anti-LH/hCG receptor antibody (L 6792, Sigma-Aldrich, Inc.) was diluted at 1:200 and the anti-GNRHR (G0920) at 1:50. Bond primary antibody diluent was used. Sections were pretreated with Bond enzyme 1 for 10 min and stained with primary antibodies for $30 \mathrm{~min}$, postprimary antibodies for $20 \mathrm{~min}$, polymer for $30 \mathrm{~min}$, and diaminobenzidine Define for $10 \mathrm{~min}$, then counterstained with hematoxylin. The sections were dehydrated in alcohol, cleared in xylene, and mounted with DPX. As a negative control, the primary antibody incubation step was omitted; testis tissue was used as a positive control for LHR and pituitary tissue for GNRHR.

The intensity of staining for specific receptor proteins in IHC was scored using a descriptive scale as follows: strong $(+++)$, moderate $(++)$, weak $(+)$, and negative $(-)$.

\section{Results}

\section{In vivo tests}

Aldosterone and cortisol responses to GNRH stimulation in the index case are shown in Fig. 1. A significant increase in plasma aldosterone $(+114 \%$ over baseline $)$ was observed before the surgery (aldosterone baseline: 22.2 and $47.6 \mathrm{ng} / \mathrm{dl}, 180 \mathrm{~min}$ after stimulation; $\mathrm{LH}$ from 7.9 to 24.3 , 90 min after GNRH; FSH: from 8.2 to 12.2, $90 \mathrm{~min}$ after GNRH), while aldosterone response was blunted after adrenalectomy.

The i.m. injection of hCG induced a significant increase $(+77 \%$ from the baseline $)$ in plasma aldosterone levels (baseline: 48.5 and $85.8 \mathrm{ng} / \mathrm{dl}$, 180 min after the stimulus). Plasma PRA and cortisol concentrations did not change during the tests. After i.m. triptorelin administration, LH levels progressively decreased, as expected, while plasma aldosterone levels progressively increased, rising to a maximum of $+120 \%$ from the baseline 22 days after the injection (Fig. 2). Plasma cortisol levels did not change during the test.

The GNRH test was performed in other 11 patients with PA, whose clinical and biochemical characteristics, and aldosterone response to GNRH stimulation are given in Table 1. Excluding the data of the index case (P1), 9 of the other 11 patients had an increase in plasma aldosterone after GNRH stimulation. In seven cases, the plasma aldosterone response ranged between +25 and $+50 \%$, while in other two patients it was +114 and $+80 \%$ ( $\mathrm{P} 2$ and $\mathrm{P} 3$ respectively). There was no cortisol or renin response to GNRH in any of the patients except for $\mathrm{P} 3$ with diagnosis of $\mathrm{AH}$ that presented a cortisol response. None of the healthy controls had a plasma aldosterone or cortisol response to the GNRH test (mean of aldosterone response expressed in \% from basal: $-30 \pm 18 \%$; range: -3 to $-50 \%$ ).

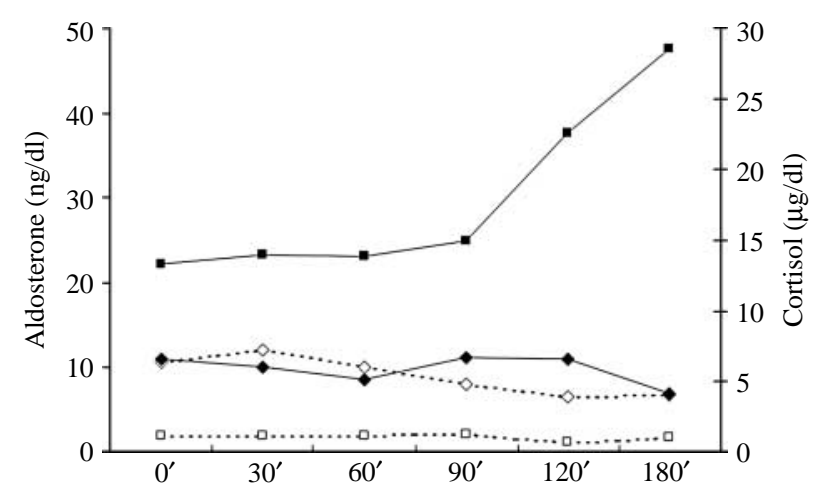

Figure 1 Aldosterone (ng/dl) (squares) and cortisol ( $\mu \mathrm{g} / \mathrm{dl})$ (diamonds) response after in vivo GNRH injection (100 $\mu \mathrm{g}$ i.v.) before (black squares and diamonds) and after (white squares and diamonds) adrenalectomy in the index case. 


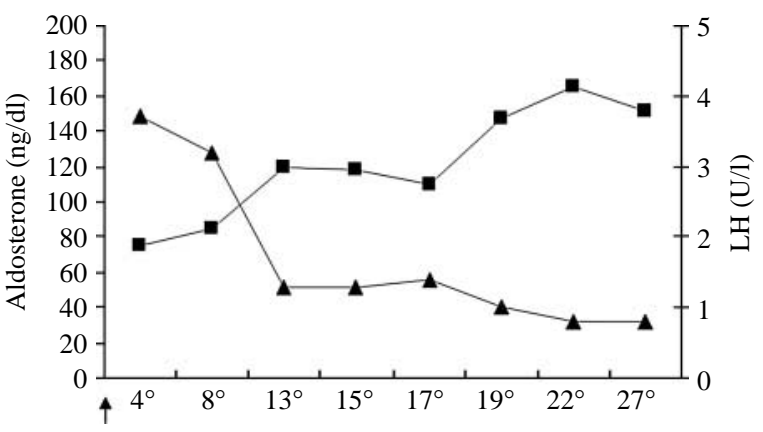

Triptorelin $3.75 \mathrm{mg}$ i.m.

Figure 2 Aldosterone (ng/dl) (squares) and LH (U/l) (triangle) variations after Triptorelin injection (3.75 $\mathrm{mg}$ i.m.) in the index case.

\section{Hormone receptor expression by real-time RT-PCR}

The results of the RT-PCR experiments are presented in Fig. 3.

The index case's aldosteronoma expressed GNRHR at the upper limit of normal adrenals, while the LHR expression was no different. The LHR expression was $>2$ S.D. above the mean of normal adrenals in 6 of 22 adrenal tissues. GNRHR expression was $>2$ s.D. above the mean of normal adrenals in 6 of 22 pathological tissues, and 2 patients had a 95- and 109-fold increase in their GNRHR transcripts.

\section{Immunohistochemistry}

The mean staining intensity at IHC was estimated visually in several areas of the pathological tissues. In the APA samples, the reaction with anti-LH antibody identified weak $(+)$, moderate $(++)$, and negative staining $(-)$ in 3,7 , and 4 pathological tissues respectively. A modest staining intensity for LHR was observed in the index case. A moderate staining for
GNRHR was observed in all seven samples examined, except that the tissue from the index case revealed a strong positivity (Fig. 4).

\section{Comparison of clinical and molecular data}

In seven patients with PA (five of APA and two of adrenal hyperplasia), the in vivo and molecular findings showed a good correlation in five patients (Table 2).

In the index case (P1), in vivo results were supported by the finding of an overexpression of GNRHR and moderate LHR expression both by RT-PCR and immunohistochemical analysis.

Patient $4(\mathrm{P} 4)$ presented a partial aldosterone response to GNRH test $(+44 \%)$ with low GNRH and LH expressions by RT-PCR but no immunohistochemical expression that could be explain by the higher sensitivity of RT-PCR compared with IHC technics.

In other patient (P6) with APA, LHR and GNRHR overexpressions were associated with a partial aldosterone response to the GNRH test $(+33 \%)$. This patient is a 34-year-old female with diagnosis of premature ovarian failure who assumed hormonal replacement therapy (HRT) with estrogen and progestin, which were discontinued 1 month before performing the GNRH test. LH response to GNRH in this patient was $150 \%$ versus a mean $\mathrm{LH}$ response of $373 \pm 157 \%$ in the other patients.

\section{Discussion}

Studies published in the past 10 years have broadened our understanding of the role of aberrant GPCR expression in the human adrenal cortex. The finding of aberrant adrenal GPCRs has provided an explanation for many puzzling clinical observations involving ACTH-independent adrenal steroid hormone overproduction. Clinical studies have shown that an abnormal

Table 1 Clinical and hormonal data of the 12 patients. Aldosterone response to GNRH stimulation test is expressed as the percentage of maximum aldosterone increase over baseline (considered as 100\%).

\begin{tabular}{|c|c|c|c|c|c|c|c|}
\hline $\mathbf{P}$ & Sex & $\begin{array}{c}\text { Age } \\
\text { (years) }\end{array}$ & $\begin{array}{c}\text { Aldosterone/PRA } \\
\text { ratio (ng/dl/ng/ml } \\
\text { per hour) }\end{array}$ & $\begin{array}{l}\text { Aldosterone after } \\
\text { sodium loading } \\
(\mathrm{ng} / \mathrm{dl})\end{array}$ & $\begin{array}{l}\text { GNRH test: } \\
\text { aldosterone } \\
\text { response (\%) }\end{array}$ & Diagnosis & $\begin{array}{l}\text { Adrenal vein sampling: } \\
\text { lateralization }\end{array}$ \\
\hline 1 & $\mathrm{~F}$ & 32 & 306 & 63 & +114 & APA & Left \\
\hline 2 & $\mathrm{M}$ & 53 & 41 & 55 & +114 & APA & Inc \\
\hline 3 & $\mathrm{M}$ & 50 & 80 & 20 & +80 & $\mathrm{AH}$ & - \\
\hline 4 & $\mathrm{~F}$ & 43 & 100 & 10 & +44 & APA & Right \\
\hline 5 & M & 60 & 118 & 15 & +41 & $\mathrm{AH}$ & Left \\
\hline 6 & $\mathrm{~F}$ & 34 & 80 & 25 & +33 & APA & Left \\
\hline 7 & $\mathrm{~F}$ & 35 & 45 & 17 & +31 & APA & Right \\
\hline 8 & $\mathrm{~F}$ & 41 & 253 & 16 & +31 & $\mathrm{AH}$ & Left \\
\hline 9 & $M$ & 40 & 46 & 27 & +30 & APA & Left \\
\hline 10 & $\mathrm{~F}$ & 42 & 360 & 56 & +26 & APA & Left \\
\hline 11 & $\mathrm{M}$ & 69 & 107 & 10 & -10 & APA & Left \\
\hline 12 & $\mathrm{M}$ & 72 & 91 & 13 & -20 & APA & Inc \\
\hline
\end{tabular}

$\mathrm{P}$, patient ( $\mathrm{P} 1$ = index case); AH, adrenal hyperplasia; APA, aldosterone-producing adenoma; AVS, adrenal venous sampling; Inc, inconclusive. 

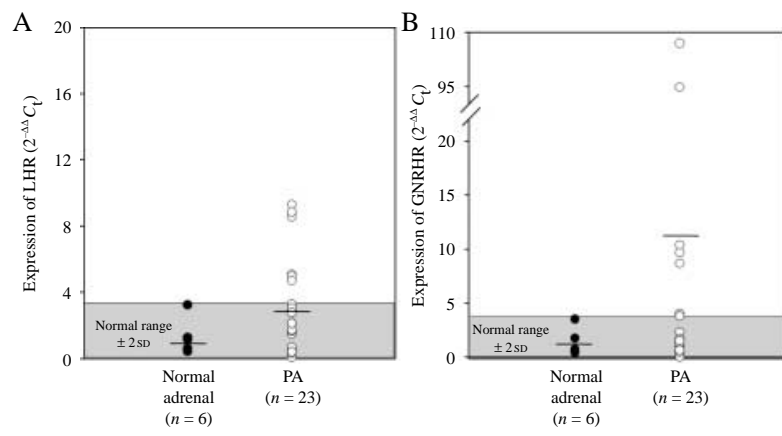

Figure 3 Expression of LHR (A) and GNRHR (B) in 23 PA tissues (filled circles) and in 6 normal adrenals (open circles).

cortisol and androgen adrenal synthesis is probably secondary to an activation of aberrant adrenal GPCRs by hormones other than ACTH (1). Molecular and animal studies have supported these findings and demonstrated that the aberrant expression of a nonmutated GPCR gene is a primary genetic event sufficient to initiate a gain-of-function leading to adrenocortical cell transformation. Thus, by transducing the nonmutated LHR gene in adrenocortical cells and performing cell transplantation in mice, Mazzuco et al. (10) showed that this single genetic event suffices to initiate the phenotypic changes conferring the capacity to form a hyperplastic tissue and a Cushing'slike syndrome.

Starting from the clinical history of a patient with PA who first developed hypertension during pregnancy, we hypothesized that high levels of hCG during pregnancy could trigger aldosterone hypersecretion through the LH/hCG receptor, abnormally expressed in the adrenal tissue. Confirming this hypothesis, we observed a positive aldosterone response after GNRH and hCG stimulation tests. Cases of ACTH-independent Cushing's
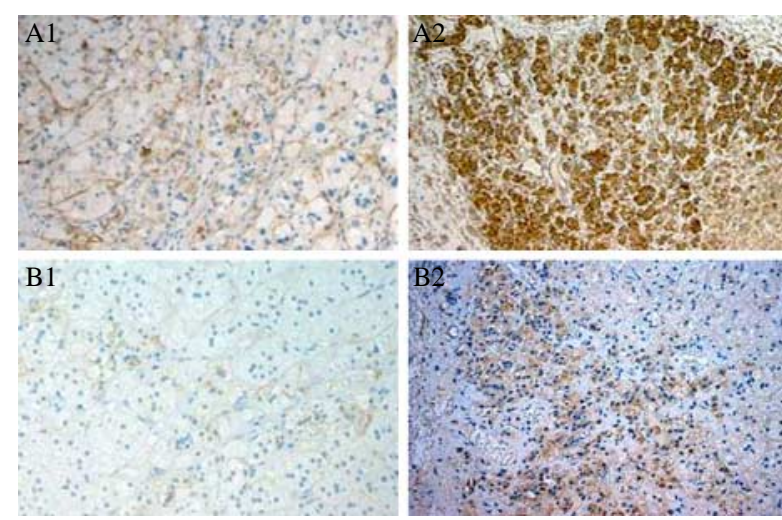

Figure 4 Immunohistochemical analysis of LHR and GNRHR in APA samples with negative staining (A1 and B1), and in APA samples with a moderate positivity (A2) for LHR and strong positivity for GNRHR (B2). Full colour version of this figure available via $h$ ttp://dx.doi.org/10.1530/EJE-10-0879. syndrome during pregnancy have already been described (11-13) and an aberrant LHR expression was recently demonstrated in a large adrenal tumor in a pregnant woman with Cushing's syndrome (14).

The LHR (which activates adenyl cyclase and phospholipase $\mathrm{C}$ to stimulate gonadal steroidogenesis) is expressed in both gonadal and nongonadal tissues (the uterus, fallopian tubes, placenta, brain, hypothalamus, and prostate) (15). In the human adrenal cortex, LHR was identified by Pabon et al. (16) primarily in the zona reticularis and inner zona fasciculata. The adrenal cortex and the somatic component of the gonads have an intimate ontogenic relationship in that they both arise from the same progenitor cells of the urogenital ridge during embryonic development (17). The reciprocal expression of adrenal- and gonad-specific genes is apparent in fetal life and disappears after birth, but may return in aberrant situations such as tumorigenesis. Proof of this lies in the finding of $\mathrm{LH}$ protein and/or mRNA in human adrenocortical adenomas, carcinomas, and macronodular adrenal hyperplasia (18). Experiments on animal models have shown that high levels of LH can induce changes in the adrenal glands, ranging from hyperplasia to the onset of adrenal tumors, and the variability of this response depends on a specific genetic background that might explain the LH-induced diseases seen in some individuals. Thus, a likely mechanism for these tumorigenic pathways has been proposed; when LH levels increase, upregulation of LHR from the pluripotent stem/progenitor cell population in the subcapsular region of the adrenal cortex is induced and Gata4 gene is activated. Gata4 then stimulates upregulation of genes normally expressed in gonadal somatic cells that, combined with additional factors such as genetic susceptibility, absence of antiproliferative effect of inhibin, and high levels of prolactin (PRL) and estrogens, induce adrenocortical hyperplasia or tumor formation (19).

Thus, high levels of hCG, PRL, and estrogens during pregnancy could have activated the mechanism of tumorigenesis in our index case. We cannot exclude that physiological LH concentrations after delivery could have also played a role in aldosterone secretion considering that LH/hCG-dependent Cushing's syndrome has also been described in premenopausal women (20), suggesting that LH in lower ranges may also regulate steroideogenesis in the presence of aberrant adrenal LHR expression.

We previously demonstrated that several APA tissues exhibit a strong LHR expression and that the transgenic expression of LHR in human adrenal cells can lead to LH-regulated aldosterone synthase expression (6). In this study, we found a variable $L H R$ mRNA expression in APA tissues, a subset of patients presenting a mild increase compared with the normal adrenal gland.

Lacroix et al. (21) described a woman with ACTHindependent adrenal hyperplasia whose Cushing's 
Table 2 Comparison of clinical and molecular data in seven primary aldosteronism patients.

\begin{tabular}{|c|c|c|c|c|c|c|}
\hline \multirow[b]{2}{*}{$\mathbf{P}$} & \multirow[b]{2}{*}{ Diagnosis } & \multirow[b]{2}{*}{$\begin{array}{l}\text { GNRH test: aldosterone } \\
\text { response }(\%)\end{array}$} & \multicolumn{2}{|c|}{ Real-time PCR } & \multicolumn{2}{|c|}{ Immunohistochemistry } \\
\hline & & & $\operatorname{LHR}\left(2^{-\Delta \Delta C_{t}}\right)$ & $\operatorname{GNRHR}\left(2^{-\Delta \Delta C_{t}}\right)$ & LHR staining & GNRHR staining \\
\hline 1 & APA & +114 & 1.5 & 4 & ++ & +++ \\
\hline 4 & APA & +44 & 0.41 & 0.64 & - & - \\
\hline 5 & $\mathrm{AH}$ & +41 & 2.21 & 0.48 & + & + \\
\hline 6 & APA & +33 & 9.75 & 3.76 & ++ & ++ \\
\hline 8 & $\mathrm{AH}$ & +31 & 0.72 & 1.24 & - & ++ \\
\hline 9 & APA & +30 & 0.33 & 0.46 & + & UN \\
\hline 10 & APA & +26 & 0.49 & 0.16 & - & UN \\
\hline
\end{tabular}

$\mathrm{P}$, patient $(\mathrm{P} 1=$ index case); $\mathrm{AH}$, adrenal hyperplasia; APA, aldosterone-producing adenoma; UN, unavailable.

syndrome emerged transiently during pregnancy and became evident after menopause. Her cortisol secretion was controlled by administering leuprolide acetate due to the long-term suppression of LH secretion. When we analyzed aldosterone response after administering a GNRH analog in our patient, however, we observed the expected LH suppression but there was also a progressive increase in aldosterone and a reduction in potassium levels, suggesting that the aldosterone response was probably linked also to GNRH stimulation. This last hypothesis was confirmed by our finding of a strong GNRHR expression on RT-PCR in the tumor tissue, by comparison with the normal adrenal, while LHR expression was moderate. Interestingly, this patient's aldosterone response to GNRH stimulation disappeared after adrenalectomy.

In our previous publication (7), we reported on a high GNRHR expression level in 11 of 28 APA samples. Zwermann et al. (8) recently found a GNRHR overexpression in 4 of $15 \mathrm{APA}$; they also found a positive aldosterone response to GNRH $(>50 \%)$ in 3 of 12 patients, and a positive correlation between clinical and molecular test findings in 2 patients.

When we extended our clinical study to another 11 patients, we found a positive aldosterone response $(>50 \%)$ to GNRH in 2 cases. The initially increased aldosterone response after GNRH stimulation was rather delayed, as in previous studies (4). No increase in cortisol levels was detected in any of the patients, except for the one with a diagnosis of $\mathrm{AH}$, hence, repeating the test under cortisol suppression with dexamethasone would probably be useful in this case. On the other hand, we found no aldosterone response to the GNRH test in healthy controls.

We studied GNRHR expression in APA samples and found a positive expression in most APA tissues with $30 \%$ of them presenting significant GNRHR levels. Several studies have explored the potential role of GNRH in extrapituitary tissues, starting from the observation that GNRH analogs can inhibit the growth of nonpituitary tumor cell lines (22). In addition to being expressed in the pituitary gland, the receptor for GNRH is found in various tissues of the reproductive system (the breast, endometrium, ovary, and prostate), in tumors derived from these tissues, and in lymphocytes. Experimental evidence has shown that this receptor and the corresponding hormone may be involved in regulating the postreceptor pathways that modulate cell proliferation, apoptosis, and angiogenesis (23). Moreover, GNRHR is able to regulate signaling pathways known to be involved in the activation of aldosterone production. These findings make its potential involvement in the pathophysiology of some cases of PA even more plausible.

GNRH, the ligand for GNRHR, is detected in humans in two forms, named GNRH1 and GNRH2, which are coded by two different genes (24). While GNRH1 is mainly expressed in the hypothalamus, GNRH2 is expressed at significantly higher levels outside the brain, particularly in the kidney, bone marrow, and prostate (25). GNRH1 and GNRH2 mRNA transcripts are also expressed in the placenta with GNRH1 being expressed throughout gestation; meanwhile, GNRH2 mRNA decreases remarkably with gestational age (26).

A recent publication by Xing et al. (27) showed that the human fetal adrenal expresses the GNRHR (about $20 \%$ of that seen in pituitary), while lowest levels were detected in adult adrenal $(1.9 \%$ of that seen in fetal adrenal). They confirmed the data of GNRH1 mRNA expression in the placenta and found a high expression of GNRH1 and GNRH2 in fetal adrenal gland, suggesting that within the fetus there is the potential for GNRH regulation of the fetal adrenal. Interestingly, when they analyzed the GNRH expression in adult adrenals they found a similar GNRH1 expression compared with fetal adrenal, while GNRH2 mRNA was significantly lower. Taken together, these data may suggest that our patient may have been exposed to high levels of placental GNRH1, which may bind to the GNRHR overexpressed in the adenomatous tissue, and this situation was maintained after pregnancy by the paracrine/autocrine action of GNRH1 expressed in the adrenal gland.

We found a correlation of clinical and molecular data in most patients except in two patients. One of them presented a partial aldosterone response to GNRH test in the presence of an overespression of LHR and GNRHR in the APA tissue. Interestingly, this was a female patient with diagnosis of premature ovarian failure and she was 
treated with estrogen and progestin that have been discontinued only 1 month before performing the GNRH test; we could hypothesize that the in vivo aldosterone response to GNRH stimulation could be partially masked by HRT.

In conclusion, this is the first study of a case of PA diagnosed during pregnancy, which appears to be related to an aberrant GNRH and LH/hCG receptor expression. Our results also suggest that a subset of patients with PA have an aberrant LH/hCG and GNRHR expressions that could modulate aldosterone secretion in pathological tissue.

More studies are necessary to clarify whether physiological or pathological conditions characterized by an increase in gonadotropins can alter adrenal function and morphology by inducing the upregulation of correlated receptors or whether the aberrant receptor expression in adrenal tissues is rather a secondary or final step in the pathogenesis of the disease.

\section{Declaration of interest}

The authors declare that there is no conflict of interest that could be perceived as prejudicing the impartiality of the research reported.

\section{Funding}

This research did not receive any specific grant from any funding agency in the public, commercial or not-for-profit sector.

\section{Acknowledgements}

We thank the technician V Guzzardo for helping with immunohistochemistry technics.

\section{References}

1 Lacroix A, N'Diaye N, Tremblay J \& Hamet P. Ectopic and abnormal hormone receptors in adrenal Cushing's syndrome. Endocrine Reviews 200122 75-110. (doi:10.1210/er.22.1.75)

2 Lacroix A, Bourdeau I, Lampron A, Mazzucco TL, Tremblay J \& Hamet P. Aberrant G-protein coupled receptor expression in relation to adrenocortical overfunction. Clinical Endocrinology 200973 1-15. (doi:10.1111/j.1365-2265.2009.03689.x)

3 Lefebvre H, Cartier D, Duparc C, Lihrmann I, Contesse V, Delarue C, Godin M, Fischmeister R, Vaudry H \& Kuhn JM. Characterization of serotonin 4-receptors in adrenocortical aldosterone-producing adenomas: in vivo and in vitro studies. Journal of Clinical Endocrinology and Metabolism $2002 \mathbf{8 7}$ 1211-1216. (doi:10.1210/jc.87.3.1211)

4 Lampron A, Bourdeau I, Oble S, Godbout A, Schürch W, Arjane P, Hamet P \& Lacroix A. Regulation of aldosterone secretion by several aberrant receptors including for glucose-dependent insulinotropic peptide in a patient with an aldosteronoma. Journal of Clinical Endocrinology and Metabolism 200994 750-756. (doi:10. 1210/jc.2008-1340)

5 Perraudin V, Delarue C, Lefebvre H, Do Rego JL, Vaudry H \& Kuhn JM. Evidence for a role of vasopressin in the control of aldosterone secretion in primary aldosteronism: in vitro and in vivo studies. Journal of Clinical Endocrinology and Metabolism 200691 1566-1572. (doi:10.1210/jc.2005-1453)

6 Saner-Amigh K, Mayhew BA, Mantero F, Schiavi F, White PC, Rao CV \& Rainey WE. Elevated expression of luteinizing hormone receptor in aldosterone-producing adenomas. Journal of Clinical Endocrinology and Metabolism 200691 1136-1142. (doi:10. 1210/jc.2005-1298)

7 Ye P, Mariniello B, Mantero F, Shibata H \& Rainey WE. G-proteincoupled receptors in aldosterone-producing adenomas: a potential cause of hyperaldosteronism. Journal of Endocrinology 2007195 39-48. (doi:10.1677/JOE-07-0037)

8 Zwermann O, Suttmann Y, Bidingmaier M, Beuschlein F \& Reincke M. Screening for membrane hormone receptor expression in primary aldosteronism. European Journal of Endocrinology 2009 $160443-451$. (doi:10.1530/EJE-08-0711)

9 Funder JW, Carey RM, Fardella C, Gomez-Sanchez CE, Mantero F, Stowasser M, Young WF Jr \& Montori VM. Endocrine Society. Case detection, diagnosis, and treatment of patients with primary aldosteronism: an Endocrine Society clinical practice guideline. Journal of Clinical Endocrinology and Metabolism 200893 3266-3281. (doi:10.1210/jc.2008-0104)

10 Mazzuco TL, Chabre O, Feige JJ \& Thomas M. Aberrant expression of human luteinizing hormone receptor by adrenocortical cells is sufficient to provoke both hyperplasia and Cushing's syndrome features. Journal of Clinical Endocrinology and Metabolism 200691 196-203. (doi:10.1210/jc.2005-1975)

11 Reschini E, Giustina G, Crosignani PG \& D'Alberton A. Spontaneous remission of Cushing's syndrome after termination of pregnancy. Obstetrics and Gynecology 197851 598-602. (doi:10. 1097/00006250-197805000-00019)

12 Close CF, Mann MC, Watts JF \& Taylor KG. ACTH-independent Cushing's syndrome in pregnancy with spontaneous resolution after delivery: control of the hypercortisolism with metyrapone. Clinical Endocrinology 199339 375-379. (doi:10.1111/j.13652265.1993.tb02380.x)

13 Wallace C, Toth EL, Lewanczuk RZ \& Siminoski K. Pregnancyinduced Cushing's syndrome in multiple pregnancies. Journal of Clinical Endocrinology and Metabolism 199681 15-21. (doi:10. 1210/jc.81.1.15)

14 Rask E, Schvarcz E, Hellman P, Hennings J, Karlsson FA \& Rao CV. Adrenocorticotropin-independent Cushing's syndrome in pregnancy related to overexpression of adrenal luteinizing hormone/ human chorionic gonadotropin receptors. Journal of Endocrinological Investigation $200932313-316$.

15 Rao CV. The beginning of a new era in reproductive biology and medicine: expression of low levels of functional luteinizing hormone/human chorionic gonadotropin receptors in nongonadal tissues. Journal of Physiology and Pharmacology $1996 \mathbf{4 7}$ (Supplement 1) 41-53.

16 Pabon JE, Li X, Lei ZM, Sanfilippo JS, Yussman MA \& Rao CV. Novel presence of luteinizing hormone/chorionic gonadotropin receptors in human adrenal glands. Journal of Clinical Endocrinology and Metabolism 199681 2397-2400. (doi:10.1210/ jc.81.6.2397)

17 Keegan CE \& Hammer GD. Recent insights into organogenesis of the adrenal cortex. Trends in Endocrinology and Metabolism 2002 13 200-208. (doi:10.1016/S1043-2760(02)00602-1)

18 Carlson HE. Human adrenal cortex hyperfunction due to LH/hCG. Molecular and Cellular Endocrinology 2007269 46-50. (doi:10. 1016/j.mce.2006.06.014)

19 Bernichtein S, Alevizaki M \& Huhtaniemi I. Is the adrenal cortex a target for gonadotropins? Trends in Endocrinology and Metabolism 200819 231-238. (doi:10.1016/j.tem.2008.06.003)

20 Feelders RA, Lamberts SW, Hofland LJ, van Koetsveld PM, VerhoefPost M, Themmen AP, de Jong FH, Bonjer HJ, Clark AJ, van der Lely AJ \& de Herder WW. Luteinizing hormone (LH)-responsive Cushing's syndrome: the demonstration of LH receptor messenger ribonucleic acid in hyperplastic adrenal cells, which respond to chorionic gonadotropin and serotonin agonists in vitro. Journal of Clinical Endocrinology and Metabolism 200388 230-237. (doi:10. 1210/jc.2002-020621)

21 Lacroix A, Hamet P \& Boutin JM. Leuprolide acetate therapy in luteinizing hormone-dependent Cushing's syndrome. New England Journal of Medicine 199918 1577-1581. (doi:10.1056/NEJM 199911183412104) 
22 Schally AV, Comaru-Schally AM \& Redding TW. Antitumor effects of analogs of hypothalamic hormones in endocrine-dependent cancers. Proceedings of the Society for Experimental Biology and Medicine 1984175 259-281.

23 Cheung LWT \& Wong AST. Gonadotropin-releasing hormone: GnRH receptor signaling in extrapituitary tissues. FEBS Journal 2008275 5479-5495. (doi:10.1111/j.1742-4658.2008.06677.x)

24 Chen A, Yahalom D, Ben-Aroya N, Kaganovsky E, Okon E \& Koch Y. A second isoform of gonadotropin-releasing hormone is present in the brain of human and rodents. FEBS Letters 1998 435 199-203. (doi:10.1016/S0014-5793(98)01064-3)

25 White RB, Eisen JA, Kasten TL \& Fernald RD. Second gene for gonadotropin-releasing hormone in humans. PNAS 199895 305-309. (doi:10.1073/pnas.95.1.305)
26 Chou CS, Beristain AG, MacCalman CD \& Leung PC. Cellular localization of gonadotropin-releasing hormone (GnRH) I and GnRH II in first-trimester human placenta and decidua. Journal of Clinical Endocrinology and Metabolism 200489 1459-1466. (doi:10.1210/jc.2003-031636)

27 Xing Y, Nakamura Y \& Rainey WE. G protein-coupled expression in the adult and fetal adrenal glands. Molecular and Cellular Endocrinology $2009 \mathbf{3 0 0} \quad 43-50 . \quad$ (doi:10.1016/j.mce.2008. 10.036)

Received 4 December 2010

Accepted 21 December 2010 